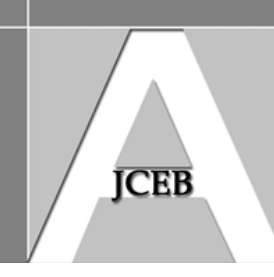

\title{
Investigating the Factors Associated with Job Satisfaction of Construction Workers in South Australia
}

M. Reza Hosseini, Nicholas Chileshe (University of South Australia, Australia)

George Zillante (University of Adelaide, Australia)

\begin{abstract}
The purpose of this paper is twofold. Firstly, its aim is to ascertain the major aspects of job satisfaction for South Australian construction workers including the main ramifications of job satisfaction in the working environment. Secondly, it investigates the influence of key agerelated factors i.e. chronological age, organisational age and length of service on major aspects of job satisfaction. The collected data for this study comprised 72 questionnaires completed by construction practitioners working at operational levels in the South Australian construction industry. Based on the responses from the target group, this study deduced that job dissatisfaction was predominantly related to the adverse impact on personal health and quality of life. In addition, indifference and the perception of dejection in the workplace are the main consequences of low levels of job satisfaction. Inferential analyses revealed that none of the age-related factors could significantly affect the major aspects of job satisfaction of construction workers in the South Australian context. The study concludes with providing practical suggestions for redesigning human resources practices for increasing the level of job satisfaction within the South Australian construction industry.
\end{abstract}

Keywords: Job satisfaction, workers, age, construction industry, South Australia

\section{Introduction}

Workers are the primary resource in construction projects, as the level of performance on construction sites is largely determined by workers' performance (Ghoddousi et al. 2014). Against this backdrop, job satisfaction levels impact on a wide range of workers' attitudes towards their jobs (Marzuki, Permadi and Sunaryo 2012), which according to Costen (2012) could directly influence the profitability of organisations. Therefore, "it is important to understand what influences an employee's job satisfaction" (Costen 2012, p. 292). In this context, the issues pertaining to job satisfaction seem to be crucial for the Australian construction industry. According to Blanchflower and Oswald (2005, p. 309) "Australia is near the bottom of the international league table on job satisfaction levels". This low ranking is worsened by the shortage of construction workers (Lingard and Francis 2004) exacerbated by high rates of staff turnovers within the Australian construction industry (Davies and Hassett 2006).

Conversely, review of literature detects the paucity of research on job satisfaction as acknowledged by Giritli, Sertyesilisik and Horman (2013). In addition, the available research on job satisfaction within the construction industry is presented in mixed and inconsistent findings (Chileshe and Haupt 2010; Onukwube 2012). In essence, as far as job satisfaction is concerned "little research has been undertaken regarding its application to the construction industry" as postulated by Onukwube (2012, p. 44). In view of the prevalence of problems with job satisfaction in Australia as previously discussed, the level of knowledge regarding job satisfaction of workers in the Australian construction context is in its infancy. Therefore, conducting further studies to investigate major aspects of this topic in the Australian construction context becomes very relevant. This has been the driving force behind conducting this study. Furthermore, the recommendations of previous studies such as the study by Chileshe and Haupt (2010), stressing the necessity of further studies to avail more 
literature through conducting investigations within different economies and cultures, has been an impetus to the present study.

In addition, in developed countries like Australia, there is growing concern about having an ageing workforce due to the increasing retirement age (Roelen et al. 2014). In this context, Järvholm et al. (2014) suggest that a deep appreciation of the interplay between job and agerelated attributes would facilitate uncovering the most effective measures to prolong the valuable participation of workers within construction activities. Nonetheless, research on job satisfaction has been, for the most part, focused on investigating the situational factors affecting job satisfaction of workers and has overlooked the individual-based features (Templer 2012), particularly age-related factors as pointed out by Kooij et al. (2008).

As a consequence of the gaps in the body of knowledge in the construction industry, this study intends to fulfil the following objectives:

1) Ascertaining the major aspects of job satisfaction for Australian construction workers

2) Investigating if key age-related attributes e.g. chronological age, organisational age and length of service could influence the views of construction workers in regards to job satisfaction aspects

This could contribute to the field, as according to Krumm, Grube and Hertel (2013) defining the factors affecting job satisfaction of workers in terms of aging could make available valuable guidelines for enhancing human resource practices, in order to maintain highmorale of workers within organisations.

\section{Literature Review}

\section{Definition of Job Satisfaction}

As a widely-accepted definition, many construction studies e.g. (Chileshe and Haupt 2010; Marzuki, Permadi and Sunaryo 2012; Onukwube 2012) have adopted the definition for job satisfaction proposed by Locke (1976). According to this definition, job satisfaction is defined as the positive emotional state of an employee stemming from experiences with a job. Such definitions have looked at job satisfaction through the lenses of affective experiences. Nevertheless, the effects of job satisfaction on attitudes of workers towards their job is so profound that some researchers have defined job satisfaction as an attitude. For example, the seminal study by Weiss (2002, p. 175) stated that "as an attitude, job satisfaction is a positive (or negative) evaluative judgment one makes about one's job or job situation." Such substantial influence of job satisfaction on major aspects of workers' stances against their jobs has been described within the following section.

\section{Prominence of Job Satisfaction}

It has been stated that employees largely identify themselves with the job they do. Thus, the level to which a worker is satisfied with his/her job is of paramount significance (Onukwube 2012). According to Krumm, Grube and Hertel (2013, p. 548) "the interrelation of job satisfaction with central job-related outcomes variables is well established." Such prominence could be attributed to proven effects of job satisfaction on various central organisational outcomes (Onukwube 2012). This includes workers' absenteeism (Templer 2012; Pagán 2013), workers' turnover (Lambert, Lynne Hogan and Barton 2001; Templer 2012) and performance of workers (Templer 2012; Krumm, Grube \& Hertel 2013). Thus, impacts of job satisfaction cut across individuals and influence central aspects of organisational businesses such as organisational productivity and profit (Zhou et al. 2008; Costen 2012; Pagán 2013) alongside quality of products and services (Zhou et al. 2008).

Hosseini M R, Chileshe N \& Zillante G. 2014, 'Investigating the factors associated with job satisfaction of construction workers in South Australia’, Australasian Journal of Construction Economics and Building, 14 (3), 1-17. 
Evidence demonstrates that this is the case for the construction context as well, because according to Marzuki, Permadi and Sunaryo (2012) and Onukwube (2012), job satisfaction shapes many features of workers' behaviours towards their jobs including motivation, performance and productivity, which are central to the success of construction projects and organisations. Further, Sweis (2010) stated that job satisfaction is an important condition for the success of construction organisations because it is tightly associated with job turnover and satisfaction with life for workers. As a corollary to this, acquiring a sound appreciation of the determinants of job satisfaction becomes necessary as postulated by Lambert, Lynne Hogan and Barton (2001), and Chiu and $\mathrm{Ng}$ (2013).

\section{Determinants of Job Satisfaction}

As contended by Lambert, Lynne Hogan and Barton (2001), major determinants of job satisfaction could be classified under two main categories. One group comprises individual factors or demographic characteristics covering attributes of the workers such as age, gender, race, and education level. The other category is associated with job characteristics or work environment factors e.g. wages, promotion opportunities, working hours and relationships with peers. Yet, apart from the approach employed, the salience of individual attributes of workers and job-related features in shaping job satisfaction aspects and determinants has been endorsed in studies within the construction industry (Ling and Loo, 2013). Among the factors associated with individual attributes, age of workers becomes of utmost importance, taking into account that aging has been regarded as one of the main challenges facing the contemporary construction industry as hypothesised by Toole, Hallowell and Chinowsky (2013). Given the domestic issues of developed countries such as Australia in terms of the ageing workforce (Roelen et al. 2014), focusing on the interplay between job satisfaction features and major aspects of age for construction workers becomes relevant (Järvholm et al. 2014).

\section{Age and Job Satisfaction}

When it comes to the interplay between work and ageing, age-related concepts have been conceptualised deploying different approaches (Kooij et al. 2008). According to $\mathrm{Ng}$ and Feldman (2009), age could represent the chronological age (i.e. calendar age) or the subjective age of an employee (the self-perception of the employee regarding his/her age). Additionally, it can be defined in terms of the social age of an employee (perceptions of others about the age of the employee) and the relative age of an employee (the degree an employee is older/younger than other people in the work team). Kooij et al. (2008, p. 366), discussed the effects of organisational age or tenure defined as the "aging of individuals in jobs and organisations" reflecting the seniority of employees. Another age-related concept associated with job satisfaction has been identified as the length of service i.e. "the number of years an individual has spent working" as discussed by Oshagbemi (2000, p. 214). As illustrated in Table 1 and posited by Chileshe and Haupt (2010), studies in regards to job satisfaction in the construction industry have proposed contradictory theories regarding the effects of age on job satisfaction. As asserted by Kooij et al. (2008) such inconsistency observed in results could be attributed to the fact that different concepts of age have been deployed in different studies. In essence, the phenomenon termed as age in previous studies could have been shorthand for factors reflecting the experiential events that act over time ( $\mathrm{Ng}$ and Feldman 2010; Krumm, Grube \& Hertel 2013). As surmised by Bedeian, Ferris and Kacmar (1992), job satisfaction could be a function of factors such as experience and length of service in the industry which enhance the position of older workers in organisations and supply them with higher skills.

According to Krumm, Grube and Hertel (2013, p. 457) predictors of job satisfaction for workers vary "as a function of employees' age". Likewise, evidence attests to the great

Hosseini M R, Chileshe N \& Zillante G. 2014, 'Investigating the factors associated with job satisfaction of construction workers in South Australia’, Australasian Journal of Construction Economics and Building, 14 (3), 1-17. 
effects of chronological age on needs and expectations of human beings (Avolio and Waldman 1994). Among different age-related concepts, length of service and organisational age are correlated with chronological age (Kooij et al. 2008). Nonetheless, there is still ambiguity regarding choosing the most relevant age-related concept in regards to job satisfaction. In essence, whether the organisational age or the length of service could be better predictors for job satisfaction aspects as opposed to chronological age, has remained a matter of controversy ( $\mathrm{Ng}$ and Feldman 2009). Such disparity regarding interactions of agerelated concepts and job satisfaction calls for investigating the effects of various concepts of age on job satisfaction. This has been considered in the subject study through taking into account examining the effects of (1) chronological age, (2) organisational age and (3) length of service on major aspects of job satisfaction of construction workers.

\section{Job Satisfaction in Construction Literature}

Table 1 captures the major studies conducted in the construction context in regards to job satisfaction of employees (to the best of the researchers' knowledge). This validates the necessity of conducting further studies on the topic and investigating the veracity of previous findings in the Australian context, given the fragmentation and lack of consistency in findings, exposure of questions to different professional groups; the restricted and narrow focal points targeted by the existing studies as evident from Table 1.

Table 1: Major studies on job satisfaction in the construction context (alphabetic order)

\begin{tabular}{|c|c|c|c|}
\hline Author(s)/Years & Country & Exposure & Description of findings \\
\hline $\begin{array}{l}\text { Bowen and Cattell } \\
\text { (2008) }\end{array}$ & South Africa & Quantity surveyors & $\begin{array}{l}\text { Job satisfaction is highly reliant on } \\
\text { gender and race but is not affected by } \\
\text { age of construction practitioners. Hence, } \\
\text { discrimination in the workplace based on } \\
\text { gender and ethnicity background } \\
\text { significantly influences job satisfaction. }\end{array}$ \\
\hline
\end{tabular}

Chileshe and

Haupt (2010)

South Africa Blue-collar workers

Chileshe and

Haupt (2007)

Dabke et al. (2008) USA Tradeswomen

Davies and Australia Blue-collar workers

Hassett (2006) and old workers was not significantly
Tradeswomen in US are generally satisfied with working in construction industry but are largely dissatisfied with payments, rewards, and job security. Demographic attributes did not show any significant effect on job satisfaction. evaluating the job satisfaction. The difference of reaction between young different towards various aspects of job satisfaction.

The study ascertained the most important items of job satisfaction for workers in 3 companies in the state of Victoria. It was observed that determinants of job satisfaction include a diverse range of items including items relevant to job content as well as job context.

Hosseini M R, Chileshe N \& Zillante G. 2014, 'Investigating the factors associated with job satisfaction of construction workers in South Australia’, Australasian Journal of Construction Economics and Building, 14 (3), $1-17$. 


\begin{tabular}{|c|c|c|c|}
\hline Author(s)/Years & Country & Exposure & Description of findings \\
\hline $\begin{array}{l}\text { Giritli, Sertyesilisik } \\
\text { and Horman } \\
\text { (2013) }\end{array}$ & Turkey & $\begin{array}{l}\text { Architects / } \\
\text { Engineers }\end{array}$ & $\begin{array}{l}\text { The study concluded that there is strong } \\
\text { correlation between job satisfaction and } \\
\text { commitment to job. However, no } \\
\text { meaningful relationship was identified } \\
\text { between age and job satisfaction. }\end{array}$ \\
\hline
\end{tabular}

Leung, Chen and Hong Kong All construction High levels of job satisfaction takes:

Yu (2008) professionals
specifying the goals of project clearly, effective team work, emotional intrinsic attachment to project by workers.

\begin{tabular}{|c|c|c|}
\hline $\begin{array}{l}\text { Ling and Loo } \\
\text { (2013) }\end{array}$ & Singapore & $\begin{array}{l}\text { Construction } \\
\text { project managers }\end{array}$ \\
\hline
\end{tabular}

Despite the best designing for a job, personal characteristics of employees play a central role in job satisfaction and accordingly outcome of one's work.

Lingard and $\quad$ Australia $\quad$ Blue-collar workers
Francis (2004)

Dissatisfaction of site-based workers mostly was related to payments and work-family conflicts due to long hours of work. The study declared that younger workers need more balance between their family and working life.

\begin{tabular}{|c|c|c|c|}
\hline $\begin{array}{l}\text { Lingard and Sublet } \\
(2002) \\
\text { Lingard (2003) }\end{array}$ & Australia & Engineers & $\begin{array}{l}\text { It was observed that engineers are not } \\
\text { generally satisfied with the reward they } \\
\text { receive. It was also concluded that } \\
\text { redesign of jobs is necessary to prevent } \\
\text { engineers burnout and turnover. }\end{array}$ \\
\hline $\begin{array}{l}\text { Lingard, Francis } \\
\text { and Turner (2010) }\end{array}$ & Australia & $\begin{array}{l}\text { Project-based } \\
\text { workers }\end{array}$ & $\begin{array}{l}\text { Long working hours specifically during } \\
\text { certain project events would negatively } \\
\text { affect the level of job satisfaction of } \\
\text { workers. }\end{array}$ \\
\hline $\begin{array}{l}\text { Marzuki, Permadi } \\
\text { and Sunaryo } \\
(2012)\end{array}$ & Indonesia & $\begin{array}{l}\text { All levels of } \\
\text { workers in } \\
\text { construction } \\
\text { projects }\end{array}$ & $\begin{array}{l}\text { Job characteristics, payments, quality of } \\
\text { relationships with supervisors and } \\
\text { colleagues and job security are the main } \\
\text { determinants of job satisfaction for } \\
\text { Indonesian construction practitioners. }\end{array}$ \\
\hline $\begin{array}{l}\text { Yirenkyi-Finako } \\
\text { and Chileshe } \\
(2012)\end{array}$ & Ghana & $\begin{array}{l}\text { Blue- collar } \\
\text { workers }\end{array}$ & $\begin{array}{l}\text { The study denoted the results gained } \\
\text { previously in South Africa by Chileshe } \\
\text { and Haupt (2010). }\end{array}$ \\
\hline $\begin{array}{l}\text { Maloney and } \\
\text { McFillen (1985) }\end{array}$ & USA & Crafts & $\begin{array}{l}\text { The level of job satisfaction was found to } \\
\text { be a function of extrinsic and intrinsic } \\
\text { incentives provided by the organisation } \\
\text { alongside one's expectations about the } \\
\text { rewards he/she deserves to receive. }\end{array}$ \\
\hline $\begin{array}{l}\text { Park, Baker and } \\
\text { Lee (2008) }\end{array}$ & Korea & $\begin{array}{l}\text { Civil engineering } \\
\text { projects personnel } \\
\text { working in teams }\end{array}$ & $\begin{array}{l}\text { Level of employees' job satisfaction was } \\
\text { positively related to their individual } \\
\text { needs regarding cognition and their task } \\
\text { complexity levels. }\end{array}$ \\
\hline
\end{tabular}

Hosseini M R, Chileshe N \& Zillante G. 2014, 'Investigating the factors associated with job satisfaction of construction workers in South Australia’, Australasian Journal of Construction Economics and Building, 14 (3), $1-17$. 


\begin{tabular}{llll}
\hline Author(s)/Years & Country & Exposure & Description of findings \\
\hline Sweis (2010) & Jordan & $\begin{array}{l}\text { Jordanian } \\
\text { construction } \\
\text { companies }\end{array}$ & $\begin{array}{l}\text { The study explored the association } \\
\text { between IT adoption and job satisfaction } \\
\text { of employees. The findings established } \\
\text { that higher levels of IT adoption would } \\
\text { increase job satisfaction of employees }\end{array}$ \\
\hline
\end{tabular}

Review of literature establishes that the effects of personal attributes such as age is an overlooked area in the extant literature as endorsed by Pagán (2011). Studies from Australia have covered the effects of job-related factors, however the interactions between such factors and individual-based attributes of workers has yet to be investigated. It is contended that in view of the lack of such studies, conducting this study aimed at targeting workers in the Australian context becomes relevant and could greatly contribute to the field.

\section{Research Method}

The objectives of this paper are largely grounded in the future areas of research outlined by Chileshe and Haupt (2010), which necessitated duplicating the process as implemented in their study in other settings. Hence, the approach of the present study and its theoretical framework resemble that of the aforementioned study, albeit in a different context, for example Australia. The framework for the study covered three levels of factors comprised of control variables i.e. personal factors (age, level of experience and nature of profession of workers). The framework also covered process factors drawing upon the two-factor theory of Herzberg (6 items in Table 3) given the close link between the items and job satisfaction of workers as endorsed by Ruthankoon and Ogunlana (2003). Herzberg's theory suggests that two independent categories of factors affect job satisfaction, comprising those running from satisfied to neutral and the other category, which reflects dissatisfied to neutral (interested readers are referred to the paper by Kazaz, Manisali and Ulubeyli (2008) for discussions on different job satisfaction theories applicable to the construction context). The framework also included outcome factors showing the effects of job satisfaction on workers (8 items in Table 4).

A quantitative survey was chosen for the data collection considering the objectives of the study. A method such as this enables researchers to collect data on the background, beliefs and attitudes of a large number of respondents and accordingly generalise the findings to a population (Neuman 2006). It is acceptable to use intact survey instruments developed in previous studies (Creswell 2009), thus the same survey instrument used by Chileshe and Haupt (2010) was deployed. The questionnaire was in three main sections. The first section included demographic data asking for the age, length of service and the nature of activities of workers. The second section covered process factors to measure the job satisfaction of workers based on answers from workers (6 items illustrated in Table 3 using a 5-point Likert scale with 1 indicating very poor satisfaction to 5 reflecting very excellent satisfaction). For this section, workers were asked to express their level of satisfaction about the different aspects of their work as captured in Table 3. The third section included outcome factors (8 items as illustrated in Table 4) to gauge the effects of job satisfaction on workers in 5 categories ranging from 1 (showing worker has never experienced such effects) to 5 (implying the occurrence of an effect for a worker all the time). For this part, workers were asked to show the frequency they had been affected by the items illustrated in Table 4.

As far as chronological age is concerned, workers' could be categorised in two sets namely younger workers (under 40 years old) and older workers (40-75 years old) as discussed by

Hosseini M R, Chileshe N \& Zillante G. 2014, 'Investigating the factors associated with job satisfaction of construction workers in South Australia’, Australasian Journal of Construction Economics and Building, 14 (3), $1-17$. 
Kooij et al. (2008). Based on the classifications proposed by Morrow and McElroy (1987), organisational age could be categorised in two sets comprising (1) establishment and advancement stage in the organisation (fewer than 10 years in the organisation) and maintenance stage (i.e. more than 10 years in the organisation). According to Lynn, Cao and Horn (1996), during the establishment and advancement stage an individual is involved primarily in developing professional and organisational competence, achievement, competition and promotion. In the maintenance stage, the individual is mainly concerned with forging peer relationships. Length of service for the construction industry in the present study was divided into categories as deployed by Sarker, Crossman and Chinmeteepituck (2003) for service industry workers (i.e. 0-5, 6-10, 11-20 and more than 21 years in the industry). It became apparent that only 3 respondents had fewer than 5 years of service length. Such glaring difference in number of cases for different categories could be a source of error in hypothesis testing (Healey 2008). Additionally, Lynn et al. (1996) state that 10 years is the pivotal point for defining job-related attitudes of workers. Thus, length of service was classified in three groups (0-10, 11-20 and more than 21 years) as captured in Table 2. Given the present study used an existing instrument deployed previously by Chileshe and Haupt (2010), the validity of the questionnaire was deemed proven.

The questionnaires were targeted at members of main professional associations of contractors in South Australia (e.g. South Australia-Civil Contractors Federation and Master Builders Association of South Australia). Membership departments of professional associations agreed to send emails to their members in support of the research study and provided a list of postal addresses after researchers signed a confidentiality agreement with them. Data collection methods using clusters of targeted population as respondents is an acceptable method for administration of questionnaires when the target population is in a wide geographic area (i.e. South Australia) termed by Neuman (2006, p. 233) as "cluster sampling".

Eventually a total of 265 questionnaire packages enclosing reply-paid envelopes were sent by post, asking companies to distribute questionnaires among their employees. Of the 265 , 72 duly completed questionnaires were returned. All the statistical analyses were conducted using the IBM Statistical Package for Social Sciences (IBM SPSS version 21.0.0.0). The nature of data for statistical analysis were regarded as fit for tests valid for interval data, because Likert scale data could be treated as interval data when it comes to using statistical testing of hypotheses (Carifio and Perla 2008).

\section{Results and Discussions}

\section{Results (descriptive analysis)}

The results of the cross-tabulation as captured in Table 2 indicated that around $80 \%(27.8 \%$ plus $52.8 \%$ ) of respondents had experienced more than 10 years of service. Moreover, 50 (16 plus 34) out of 72 workers, fell within the category of old workers. This is reflective of the dominance of the aging workforce within Australia as pointed out by Roelen et al. (2014). This also endorses the need to enhance the practices of human resource management in the construction context in terms of keeping older workers happy in order to retain them, in view of shortage of skills within the Australian construction industry (Watson 2012).

The results of the descriptive statistics for the six factors to measure job satisfaction of workers are illustrated in Table 3. Since the overriding aim of ordering variables was to rank the relative importance of different variables, Holt (2014) argues that a simple approach using means of variables is valid. It is inferred from the results that major problems of Australian workers in terms of job satisfaction concern the 'personal health' (mean score = 3.611 ; rank $=6^{\text {th }}$ ) and 'quality of life' (mean score $=3.652$, rank $=5^{\text {th }}$ ). This could be

Hosseini M R, Chileshe N \& Zillante G. 2014, 'Investigating the factors associated with job satisfaction of construction workers in South Australia’, Australasian Journal of Construction Economics and Building, 14 (3), $1-17$. 
attributed to long working hours in the Australian construction industry coupled with "a subjective sense of having too much to do in the time available" ending up in work-family conflicts, mental health problems and dissatisfaction with life as described by Lingard and Francis (2004, p. 993).

Table 2: Cross-tabulation of respondents' chronological age, organisational age, and length of service

\begin{tabular}{|c|c|c|c|c|c|}
\hline \multirow[b]{2}{*}{ Chronological Age } & \multirow[b]{2}{*}{ Organisational Age } & \multicolumn{3}{|c|}{ Length of Service (Years) } & \multirow[b]{2}{*}{ Total } \\
\hline & & $0-10$ & $11-20$ & $\begin{array}{c}\text { More } \\
\text { than } 21\end{array}$ & \\
\hline \multirow{4}{*}{ 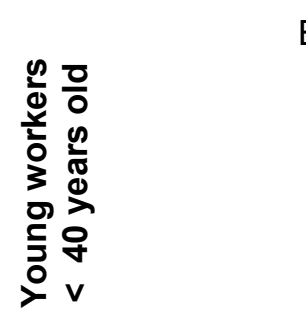 } & Establishment/Advancement Stage & 10 & 6 & 0 & 16 \\
\hline & & $45.5 \%$ & $27.3 \%$ & $0.0 \%$ & $72.7 \%$ \\
\hline & Maintenance Stage & 0 & 4 & 2 & 6 \\
\hline & & $0.0 \%$ & $18.2 \%$ & $9.1 \%$ & $27.3 \%$ \\
\hline \multirow{6}{*}{ 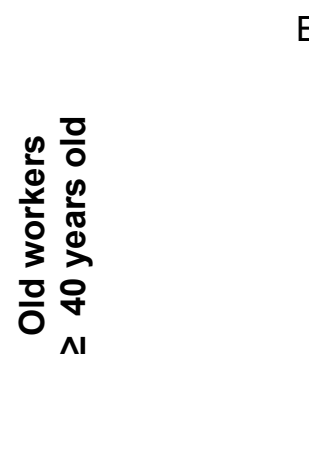 } & Establishment/Advancement Stage & 4 & 4 & 8 & 16 \\
\hline & & $8.0 \%$ & $8.0 \%$ & $16.0 \%$ & $32.0 \%$ \\
\hline & Maintenance Stage & 0 & 6 & 28 & 34 \\
\hline & & $0.0 \%$ & $12.0 \%$ & $56.0 \%$ & $68.0 \%$ \\
\hline & \multirow[t]{2}{*}{ Total } & 14 & 20 & 38 & 72 \\
\hline & & $19.4 \%$ & $27.8 \%$ & $52.8 \%$ & $100.0 \%$ \\
\hline
\end{tabular}

Poor satisfaction with personal health could stem from the fact that the nature of a wide range of activities for construction workers encompasses physical effort. Given that most workers in the Australian construction industry are not young, this could result in a subjective perception of disability to perform the job for older workers, which accordingly gives rise to job dissatisfaction as described by Pagán (2013). This is understandable as working ability and health are related, and health declines for older workers (Porcellato et al. 2010), as a justification for low scores of satisfaction with personal health in Table 3. Such an insight also becomes fathomable in view of the fact that as workers get older particularly for demanding jobs of the construction industry, health problems limit the type of activities ageing workers can perform and how well they can perform them. More to the point, such health issues become a source of concern for workers being aware that this could adversely affect their employer's view of their employability as posited by Porcellato et al. (2010).

For South Australian construction workers, 'relationship with work mates' (mean score = 4.00; rank $=1^{\text {st }}$ ) and their 'relationship with supervisors' (mean score $=3.986$; rank $=2^{\text {nd }}$ ) were perceived as the most satisfactory aspects of their jobs, similar to the case of South Africa as described by Chileshe and Haupt (2010). An explanation for this could be provided through drawing upon the contents in Table 2 . That is, around $56 \%$ of workers working in the South Australian construction context are in their maintenance stage in terms of organisational age. Thus, according to Lynn et al. (1996), their main priority is developing relationships in the workplace while they become less competitive which could lead to better

Hosseini M R, Chileshe N \& Zillante G. 2014, 'Investigating the factors associated with job satisfaction of construction workers in South Australia’, Australasian Journal of Construction Economics and Building, 14 (3), $1-17$. 
relationships in the organisation. Such good relationships with co-workers could result in assistance in work, which increases the general level of satisfaction with job for workers (Marzuki, Permadi \& Sunaryo 2012). The relative lower amounts of a measure of dispersion (namely standards deviations) for these factors as in Table 3 could be reflective of the consensus among workers.

'Personal development' (mean score $=3.722$, rank $=4^{\text {th }}$ ) and 'satisfaction with occupation' (mean score $=3.806$, rank $=3^{\text {rd }}$ ) do not represent high levels of satisfaction for construction workers. It could be inferred that construction managers should pay more attention to the concept of job enrichment. This should entail restructuring the jobs in order to make them more challenging, motivating, and satisfying to workers (Loher et al. 1985). This also could be attributed to the dominance of maintenance stage for most of the workers for which personal development and advancement is no longer a priority (Lynn et al. 1996).

Table 3: Job satisfaction scores

\begin{tabular}{|c|c|c|c|c|c|}
\hline & Job satisfaction factors & $\mathbf{N}$ & Mean & SD & Rank \\
\hline \multirow{4}{*}{ 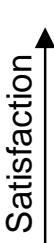 } & Personal health & 72 & 3.611 & .815 & 6 \\
\hline & Quality of life & 72 & 3.652 & .966 & 5 \\
\hline & Personal development & 72 & 3.722 & .791 & 4 \\
\hline & Satisfaction with occupation & 72 & 3.806 & .882 & 3 \\
\hline$\overline{\grave{d}}$ & Relationship with supervisor & 72 & 3.986 & .640 & 2 \\
\hline 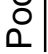 & Relationship with workmates & 72 & 4.000 & .650 & 1 \\
\hline
\end{tabular}

The results concerning the perceptions of workers on effects of job satisfaction are illustrated in Table 4 in which the main effects of job satisfaction experienced by workers are ranked utilising the Coefficient of Variation (CV). The justification for adopting the CV approach is based on the premise that the scores for each item are from individuals, thus it is tenable to take CVs as a measure of variation in each individual's assessment of importance for items. That is, ranking targets the consistency of scoring among construction workers, justifying using the least variation as recommended by Holt (2014).

Table 4: Job satisfaction effects

\begin{tabular}{|c|c|c|c|c|c|c|}
\hline \multirow{9}{*}{ 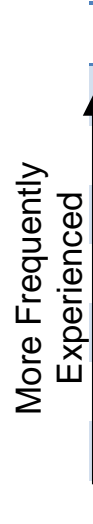 } & Job satisfaction effects & $\mathbf{N}$ & Mean¥ & Std. Dev. & $\mathrm{CV}^{*}$ & Rank \\
\hline & Indifference & 72 & 2.416 & 0.945 & 0.391 & 1 \\
\hline & Dejection & 72 & 2.180 & 1.065 & 0.488 & 2 \\
\hline & Lack of Confidence & 72 & 2.388 & 1.169 & 0.489 & 3 \\
\hline & Poor Self Image & 72 & 2.430 & 1.196 & 0.492 & 4 \\
\hline & Lack of Alertness & 72 & 2.166 & 1.074 & 0.496 & 5 \\
\hline & Poor Recognition of Abilities & 72 & 2.347 & 1.164 & 0.496 & 6 \\
\hline & Job Dissatisfaction & 72 & 2.486 & 1.278 & 0.514 & 7 \\
\hline & Lack of Motivation & 72 & 2.486 & 1.332 & 0.535 & 8 \\
\hline
\end{tabular}

Note: ${ }^{\ddagger}$ Mean score where $1=$ Very low; $2=$ Low; $3=$ Neutral; $4=$ High; and $5=$ Very High, ${ }^{*} \mathrm{CV}=$ Coefficient of Variation, the smaller the $\mathrm{CV}$ the more frequently the effect of job satisfaction is experienced within the Australian construction context.

Hosseini M R, Chileshe N \& Zillante G. 2014, 'Investigating the factors associated with job satisfaction of construction workers in South Australia’, Australasian Journal of Construction Economics and Building, 14 (3), $1-17$. 
Findings of descriptive analysis did not show similarity with the findings of the study in South Africa (Chileshe and Haupt 2010), in which indifference was identified as the least experienced item impacting workers, whereas in South Australia indifference was of the greatest influence. Indifference mostly occurs when workers are exhausted and discouraged reflecting "the stress dimension of burnout" (Maslach, Schaufeli and Leiter 2001) as discussed below.

\section{Discussions (descriptive analysis)}

It is the authors' contention that the key findings in Table 3 and Table 4 bring to light one of the dominant problems in the South Australian construction context. That is, workers have to cope with long working hours and the necessity of completing a great volume of tasks as described by Lingard and Francis (2004). In other words, serious organisational commitments lead Australian construction workers towards burnout, as pointed out by Lingard et al. (2007). Accordingly, burnout yields experiencing indifference (Maslach et al. 2001) as a common issue for Australian workers (see Table 4). Furthermore, the findings of the recent study by Francis et al. (2013) revealed that long working hours, lack of flexibility in works and serious work-family conflicts are rampant within the Australian construction industry. Figure 1 illustrates an abbreviated interpretation of the main issues of job satisfaction of South Australian construction workers as discussed above, by linking the results of Table 3, Table 4 and previous studies in the context.

Other factors experienced by the workers comprising dejection, poor self-image and poor recognition of abilities are the main problems affecting old workers (Porcellato et al. 2010). This is understandable as $70 \%$ of cases in this study were old workers. In addition, the high importance of dejection for workers further underlines the prevalence of problems pertinent to job-distress for South Australian construction workers, because dejection and agitation are the consequences of job-distress for workers, as pointed out by Reich, Wagner-Westbrook and Kressel (2007).

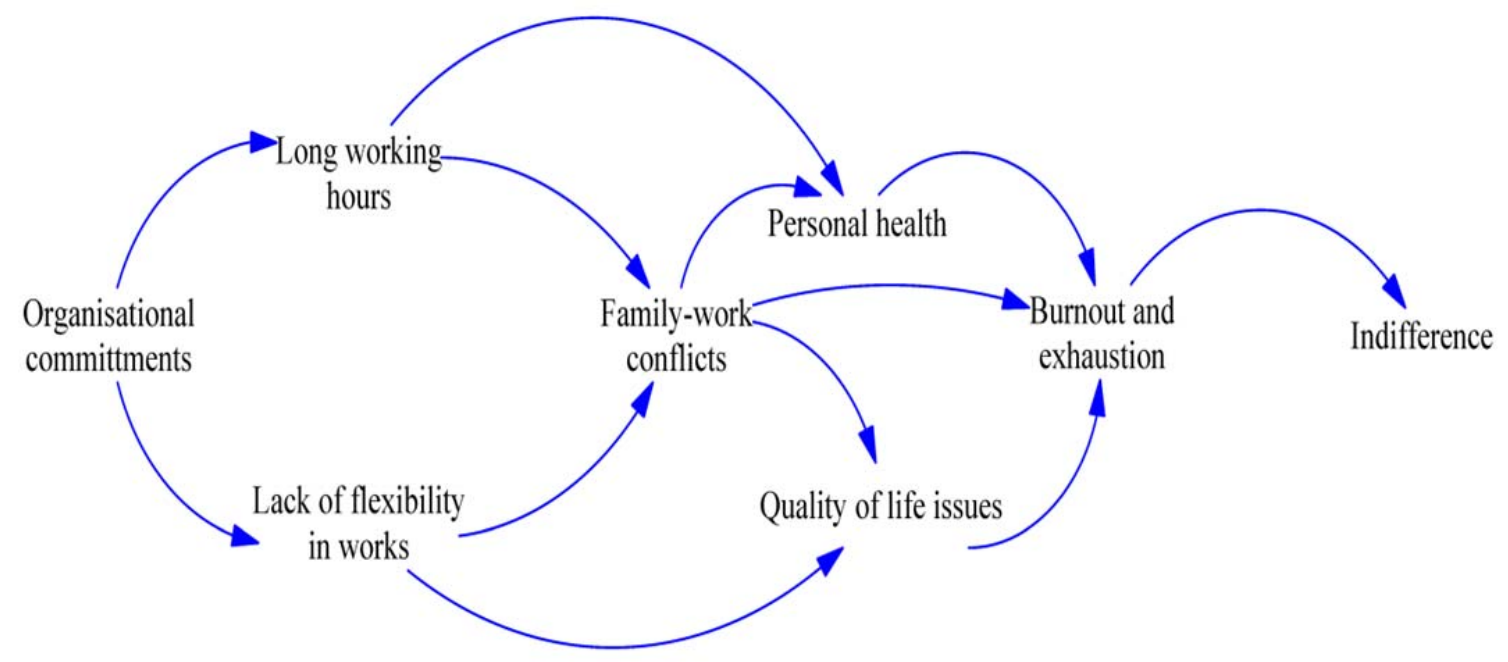

Figure 1: Main problems associated with job satisfaction in the South Australian construction industry (source: authors)

Hosseini M R, Chileshe N \& Zillante G. 2014, 'Investigating the factors associated with job satisfaction of construction workers in South Australia’, Australasian Journal of Construction Economics and Building, 14 (3), $1-17$. 


\section{Results and Discussions (inferential analysis)}

Another major objective of this study entailed investigating whether age-related factors could influence the perceptions of workers pertinent to major aspects of job satisfaction. To this end, the chronological age, organisational age and length of service were regarded as independent variables, while items reflective of job satisfaction scores and job satisfaction effects were the dependent variables. This was redolent of 3 Multivariate Analysis of Variance (MANOVA) hypothesis testing problems. That is, in each of such tests, level of significance of change of multiple dependent variables due to changes in each independent variable should be tested. To determine the description by Verma (2013, p. 224) i.e. examining if the principles of MANOVA in regards to existence of relationship between dependent variables are met, a Pearson correlation test was calculated to evaluate associations between dependent variables. Results $(r(70))$ for the tests are shown in Table 5 and Table 6.

Table 5: Pearson correlation coefficients for job satisfaction scores items

\begin{tabular}{|c|c|c|c|c|c|c|}
\hline & 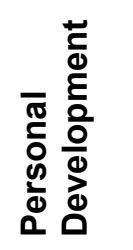 & 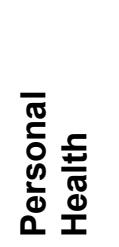 & 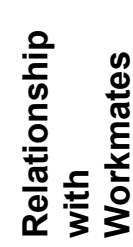 & 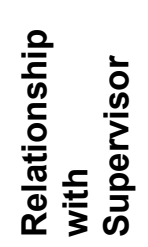 & 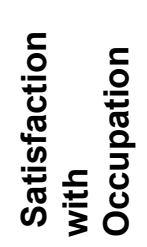 & 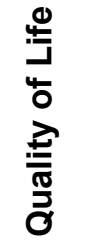 \\
\hline Personal Development & 1 & & & & & \\
\hline Personal Health & $.595^{* *}$ & 1 & & & & \\
\hline Relationship with Workmates & $.356^{* *}$ & $.266^{*}$ & 1 & & & \\
\hline Relationship with Supervisor & $.354^{* *}$ & .179 & $.644^{* *}$ & 1 & & \\
\hline Satisfaction with Occupation & $.527^{* *}$ & $.344^{* *}$ & $.491^{* *}$ & $.420^{* *}$ & 1 & \\
\hline Quality of Life & $.369^{* *}$ & $.416^{* *}$ & .202 & .175 & $.580^{* *}$ & 1 \\
\hline \multicolumn{7}{|c|}{ **. Correlation is significant at the 0.01 level (2-tailed). } \\
\hline *. Correlation is significant at $t$ & ailed). & & & & & \\
\hline
\end{tabular}

Table 6: Pearson correlation coefficients for job satisfaction effects items

\begin{tabular}{|c|c|c|c|c|c|c|}
\hline 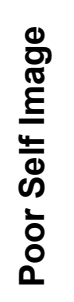 & 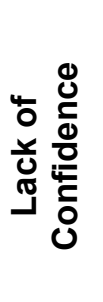 & 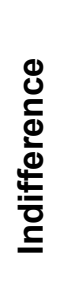 & 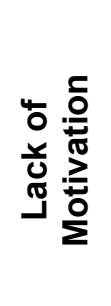 & 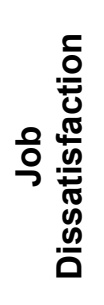 & 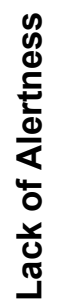 & 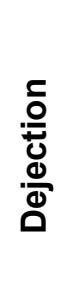 \\
\hline
\end{tabular}

\begin{tabular}{|c|c|c|c|c|c|c|c|}
\hline Poor Self Image & 1 & & & & & & \\
\hline Lack of Confidence & $.714^{* *}$ & 1 & & & & & \\
\hline Indifference & $.549^{* *}$ & $.526^{\star *}$ & 1 & & & & \\
\hline Lack of Motivation & $.547^{* *}$ & $.582^{* *}$ & $.541^{* *}$ & 1 & & & \\
\hline Job Dissatisfaction & $.626^{* \pi}$ & $.767^{\star *}$ & $.611^{* *}$ & $.860^{* *}$ & 1 & & \\
\hline Lack of Alertness & $.612^{* *}$ & $.710^{* *}$ & $.651^{* *}$ & $.592^{* *}$ & $.699^{* *}$ & 1 & \\
\hline Dejection & $.546^{\star *}$ & $.666^{* *}$ & $.707^{\star *}$ & $.642^{* *}$ & $.731^{\star *}$ & $.797^{\star *}$ & 1 \\
\hline Poor Recognition of & $.609^{* *}$ & $.665^{* *}$ & $.634^{* *}$ & $.580^{* *}$ & $.670^{* *}$ & $.763^{* *}$ & $.777^{* *}$ \\
\hline
\end{tabular}

Abilities

**. Correlation is significant at the 0.01 level (2-tailed).

Hosseini M R, Chileshe N \& Zillante G. 2014, 'Investigating the factors associated with job satisfaction of construction workers in South Australia', Australasian Journal of Construction Economics and Building, 14 (3), 1-17. 
As can be seen from Table 5 and Table 6 , scores for job satisfaction items and effects of job satisfaction items are related to each other. In such cases, in order to investigate the effects of independent variables on a group of related items, MANOVA becomes relevant (Verma, 2013), because conducting several univariate tests for each item results in Type I error inflation, according to Cronk (2012). That is, many sources of error are contained in case of MANOVA, as all the statistical tests are examined at the same time as suggested by Abbott (2011). According to Cronk (2012, p. 87) "multivariate tests look at all dependent variables at once in much the same way that ANOVA looks at all levels of independent variables at once."

A one-way MANOVA was calculated for examining the effects of chronological age, organisational age and length of service on items of job satisfaction scores and job satisfaction effects, as illustrated in Table 7. Hypothesis testing drew upon the most widelyused test in such multivariate tests namely Wilks' Lambda as recommended by Cronk (2012). As inferred from Table 7, (Lambda $(6,65)=.902, p=.328)$ none of the items representing job satisfaction scores of South Australian workers were significantly affected by chronological age. It was similarly the case for job satisfaction effects on workers $(\operatorname{Lambda}(8,63)=.829, p=.135)$. Consequently, scores of job satisfaction and effects of job satisfaction on construction workers are not affected by the chronological age of workers as previously posited by Chileshe and Haupt (2010) for South Africa. This also reiterates the findings by $\mathrm{Ng}$ and Feldman (2010), suggesting that the perceptions of workers in regards to job satisfaction aspects are not influenced by their age.

Table 7: Results of comparing job satisfaction scores/effects between different categories of age-related factors (chronological age, organisational age and length of service) as defined in Table 2

\begin{tabular}{|c|c|c|c|c|c|c|}
\hline \multirow[t]{2}{*}{ Dependent variables } & \multirow[t]{2}{*}{ Age-related factor } & \multicolumn{5}{|c|}{ Wilks' Lambda results } \\
\hline & & Value & $F$ & $\begin{array}{l}\text { Hypothesis } \\
\qquad d f^{a}\end{array}$ & Error $d f$ & Sig. \\
\hline \multirow[t]{3}{*}{ Job satisfaction scores } & Chronological age & .902 & $1.180^{\mathrm{b}}$ & 6.000 & 65.000 & .328 \\
\hline & Organisational age & .908 & $1.093^{b}$ & 6.000 & 65.000 & .376 \\
\hline & Length of service & .807 & $1.211^{b}$ & 12.000 & 128.000 & .283 \\
\hline \multirow[t]{3}{*}{ Job satisfaction effects } & Chronological age & .829 & $1.626^{b}$ & 8.000 & 63.000 & .135 \\
\hline & Organisational age & .931 & $.584^{\mathrm{b}}$ & 8.000 & 63.000 & .787 \\
\hline & Length of service & .819 & $.814^{\mathrm{b}}$ & 16.000 & 124.000 & .668 \\
\hline \multicolumn{7}{|l|}{ a. Degree of Freedom } \\
\hline b. Exact statistic & & & & & & \\
\hline
\end{tabular}

Outcome of one-way MANOVA captured in Table 7 also showed no significant effect for organisational age on scores and effects of job satisfaction for South Australian construction workers. Results indicated that there is no difference between job satisfaction scores of workers in terms of the stage of organisational age they are in $(\operatorname{Lambda}(6,65)=.908, p$ $=.376$ ). Additionally, job satisfaction effects for workers in their establishment/advancement stage is the same for workers in the maintenance stage in organisations $(\operatorname{Lambda}(8,63)=$ .931, $p=.787$ ). Therefore, major aspects of job satisfaction for South Australian construction workers do not depend on the time they have been working for their organisations. This finding was consistent with the proposition put forward by Kooij et al. (2008), that organisational age effects are moderated by the positive effects of higher earnings of senior

Hosseini M R, Chileshe N \& Zillante G. 2014, 'Investigating the factors associated with job satisfaction of construction workers in South Australia’, Australasian Journal of Construction Economics and Building, 14 (3), $1-17$. 
workers and the negative effects of carrier plateaus. This could also be explained by the moderating effects of improvement of their jobs and higher economic wealth of workers in higher organisational ages as argued by Krumm, Grube \& Hertel (2013).

Results as captured in Table 7 implied that there is no significant difference between job satisfaction scores of workers in different categories of length of service $(\operatorname{Lambda}(12,128)=$ $.807, p=.283$ ). Likewise, job satisfaction effects for workers in their initial stages of service in the construction industry was the same for workers in the later stages in the industry $(\operatorname{Lambda}(16,124)=.819, p=.668)$. This finding is in contrast to many studies advocating the effects of length of service stage on all major job attitudes including job satisfaction. (See (Kooij et al. 2008) for a list of references finding positive relationships between higher levels of length of service and job satisfaction). The study by Krumm, Grube \& Hertel (2013) highlights such inconsistency in results of previous studies by arguing that the relationship between job satisfaction aspects and age-related factors is much more complicated than assumed by investigators. As posited by Kooij et al. (2008), length of service has ambiguous effects on job satisfaction of workers. On one hand, it has negative effects such as skill obsolescence and reaching career plateau, which make workers feel detached from their jobs. On the other hand, workers in later stages of careers can take advantage of monetary incentives, changing the nature of needs, increase in work commitment and higher career resilience.

As a result, age-related factors might be regarded as the moderators for effects of a wide range of factors influencing major aspects of job satisfaction for workers. As postulated by Krumm, Grube \& Hertel (2013, p. 559) "it is likely that different aspects of work-related satisfaction differently contribute to job satisfaction in different age groups." Moreover, the relationship between job satisfaction and age-related factors is largely context-based affected by the socioeconomic environment dominating workplaces for older and senior workers. This would explain the controversy in the body of knowledge in regards to the relationship between age-related factors and job satisfaction. In this context, pertinent laws (e.g. Age Discrimination Act 2004), monetary incentives and socioeconomic environment in South Australia might have compensated for the negative effects of age-related factors for older workers according to the results of the present study. This might not be the case for Turkey in which job satisfaction is affected by age-related factors as shown by the findings of Giritli, Sertyesilisik \& Horman (2013).

\section{Conclusion and Further Research}

Evidence demonstrates that serious organisational commitments and long hours of working could be a major contributor to low job satisfaction levels for South Australian construction workers. As such, the managerial implications for the present study could be presented as follows:

1- Construction managers in South Australia have to pay more attention to restructuring and redesigning the scheduling limitations and the amount of tasks assigned to workers.

2- Human resource practices addressing age-related factors in South Australia have succeeded in moderating the negative effects of age-related factors. However, this could be enhanced by providing opportunity for promotion for older workers, given the significant effects of promotion opportunity on job satisfaction levels in the construction industry as asserted by Fuentes-del-Burgo and Navarro-Astor (2014).

3- Modifying human resources management practices should promote increasing apprenticeship opportunities in projects to replace older workers and taking the opportunity to transfer soft skills of experience, as discussed in great length by

Hosseini M R, Chileshe N \& Zillante G. 2014, 'Investigating the factors associated with job satisfaction of construction workers in South Australia’, Australasian Journal of Construction Economics and Building, 14 (3), $1-17$. 
Watson (2012). This also would moderate the negative effects of skills obsolesce (see (Kooij et al. 2008)) of existing older workers by exposing them to the updated knowledge of beginners and young workers. This gives them motivation to acquire the new skills required to meet the requirements of a progressively changing working environment.

The findings brought to light the fact that perceptions of workers in regards to job satisfaction do not change on account of their chronological age, organisational age and length of service. Yet, in view of the glaring disparity between such an insight and the findings of previous studies, this could be attributed to the influence of context on the relationship between age-related factors and major aspects of job satisfaction. That is, the nature of associations between age-related factors and job satisfaction have been observed to be dissimilar in different countries and socioeconomic contexts.

Although this study contributes to the field, some limitations might affect the findings. Firstly, the sample size is small and applies only to one state in Australia, in which industrial relations and regulations might be different from the rest of the country. Cautionary findings should be considered for the rest of the country. Additionally, a major part of the cases belonged to older workers category, which might affect the comparison between the two samples of the study. Therefore, this study could be regarded as a rudimentary effort to picture a snapshot of the conditions in need of attention. Moreover, the study points to a need for further inquiries entailing the investigation of effects of task allocation policies of construction managers on job satisfaction of workers in Australia. Furthermore, in the Australian context, future researchers should ascertain the main issues behind the negative views of workers towards their health and quality of life. The findings also attested to the complicated nature of relationships between the context, age-related factors and job satisfaction of workers. This signals the need for future investigators to examine the antecedents of job satisfaction in different age groups and different socioeconomic contexts in more detail.

\section{Acknowledgement}

This paper provides a background to the successful divisional Early Career Researcher grant (ECR) of Division of Information Technology, Engineering and the Environment, University of South Australia: Impact of Age on the Job Satisfaction of Construction Workers in South Australia. The authors wish to thank Civil Contractors Federation (CCF) in South Australia for the generous help and support while conducting this project.

\section{References}

Abbott, M.L. 2011, Understanding educational statistics using Microsoft Excel ${ }^{\circledR}$ and SPSS ${ }^{\circ}$, Wiley, Hoboken, NJ.

Avolio, B.J. \& Waldman, D.A. 1994, 'Variations in cognitive, perceptual, and psychomotor abilities across the working life span: examining the effects of race, sex, experience, education, and occupational type', Psychology and Aging, 9 (3), 430-442.

Bedeian, A.G., Ferris, G.R. \& Kacmar, K.M. 1992, 'Age, tenure, and job satisfaction: A tale of two perspectives', Journal of Vocational Behavior, 40 (1), 33-48.

Blanchflower, D.G. \& Oswald, A.J. 2005, 'Happiness and the Human Development Index: The Paradox of Australia', Australian Economic Review, 38 (3), 307-318.

Bowen, P. \& Cattell, K. 2008, 'Job satisfaction of South African quantity surveyors', Engineering, Construction and Architectural Management, 15 (3), 260-269.

Hosseini M R, Chileshe N \& Zillante G. 2014, 'Investigating the factors associated with job satisfaction of construction workers in South Australia’, Australasian Journal of Construction Economics and Building, 14 (3), $1-17$. 
Carifio, J. \& Perla, R. 2008, 'Resolving the 50-year debate around using and misusing Likert scales', Medical Education, 42 (12), 1150-1152.

Chileshe, N. \& Haupt, T.C. 2007, 'Age Influences on the Job Satisfaction of Construction Workers: Evidence from South Africa', in D. Boyd (ed), 23rd Annual ARCOM Conference, Association of Researchers in Construction Management, 3-5 September, Belfast, UK, 389-398.

Chileshe, N. \& Haupt, T.C. 2010, 'The effect of age on the job satisfaction of construction workers', Journal of Engineering, Design and Technology, 8 (1), 107-118.

Chiu, W.Y.B. \& Ng, F.F. 2013, 'Improvement of Job Satisfaction and Organisational Commitment through Work Group Identification: An Examination of the Quantity Surveyors in Hong Kong', Australasian Journal of Construction Economics \& Building, 13 (3), 80-95.

Costen, W.M. 2012, 'Job Satisfaction', in R.K. Prescott \& W.J. Rothwell (eds), Encyclopedia of Human Resource Management, Volume 1, Short entries, Pfeiffer: A Wiley Imprint, San Francisco.

Creswell, J.W. 2009, Research design: Qualitative, quantitative, and mixed methods approaches, Sage Publications, Inc., Thousand Oaks, California.

Cronk, B.C. 2012, How to Use SPSS : a step-by-step guide to analysis and interpretation, 7th edn, Pyrczak Pub., Glendale, CA.

Dabke, S, Salem, O, Genaidy, A. \& Daraiseh, N. 2008, 'Job Satisfaction of Women in Construction Trades', Journal of Construction Engineering and Management, 134 (3), 205-216.

Davies, H. \& Hassett, B. 2006, 'The degree of job satisfaction experienced by site-based construction professionals', in G. Runeson \& R. Best (eds), The 31st Australian University Building Educators Association Annual Conference (AUBEA) University of Technology, 11-14 July, Sydney, NSW, 1-13.

Francis, V, Lingard, H, Prosser, A. \& Turner, M. 2013, 'Work-Family and Construction: Public and Private Sector Differences', Journal of Management in Engineering, 29 (4), 392-399.

Fuentes-del-Burgo, J. \& Navarro-Astor, E. 2014, 'Building Engineers' Promotion and Its Effect on Job Satisfaction. A Qualitative Study of Site Managers in Castilla-la Mancha', in C. Llinares-Millán et al. (eds), Construction and Building Research, Springer, Netherlands, 27-33.

Ghoddousi, P, Bahrami, N, Chileshe, N. \& Hosseini, M.R. 2014, 'Mapping site-based construction workers' motivation: Expectancy theory approach', Australasian Journal of Construction Economics and Building, 14 (1), 60-77.

Giritli, H, Sertyesilisik, B. \& Horman, B. 2013, 'An investigation into job satisfaction and organizational commitment of construction personnel', Global Advanced Research Journal of Social Science, 2 (1), 1-11.

Healey, J.F. 2008, Statistics : a tool for social research, 8th edn, Wadsworth Cengage Learning, Belmont, California.

Holt, G.D. 2014, 'Asking questions, analysing answers: relative importance revisited', Construction Innovation: Information, Process, Management, 14 (1), 2-16.

Järvholm, B, Stattin, M, Robroek, S.J, Janlert, U, Karlsson, B. \& Burdorf, A. 2014, 'Heavy work and disability pension-a long term follow-up of Swedish construction workers', Scandinavian journal of work, environment \& health (in press).

Kazaz, A, Manisali, E. \& Ulubeyli, S. 2008, 'Effect of basic motivational factors on construction workforce productivity in turkey', Journal of Civil Engineering and Management, 14 (2), 95-106.

Kooij, D, De Lange, A, Jansen, P. \& Dikkers, J. 2008, 'Older workers' motivation to continue to work: Five meanings of age: A conceptual review', Journal of Managerial Psychology, 23 (4), 364-394.

Krumm, S, Grube, A. \& Hertel, G. 2013, 'No time for compromises: Age as a moderator of the relation between needs-supply fit and job satisfaction', European Journal of Work and Organizational Psychology, 22 (5), 547-562.

Hosseini M R, Chileshe N \& Zillante G. 2014, 'Investigating the factors associated with job satisfaction of construction workers in South Australia’, Australasian Journal of Construction Economics and Building, 14 (3), $1-17$. 
Lambert, E.G, Lynne Hogan, N. \& Barton, S.M. 2001, 'The impact of job satisfaction on turnover intent: a test of a structural measurement model using a national sample of workers', The Social Science Journal, 38 (2), 233-250.

Leung, M, Chen, D. \& Yu, J. 2008, 'Demystifying Moderate Variables of the Interrelationships among Affective Commitment, Job Performance, and Job Satisfaction of Construction Professionals', Journal of Construction Engineering and Management, 134 (12), 963-971.

Ling, F. \& Loo, C. 2013, 'Characteristics of Jobs and Jobholders that Affect Job Satisfaction and Work Performance of Project Managers', Journal of Management in Engineering (in press).

Lingard, H. \& Sublet, A. 2002, 'The impact of job and organizational demands on marital or relationship satisfaction and conflict among Australian civil engineers', Construction Management and Economics, 20 (6), 507-521.

Lingard, H. 2003, 'The impact of individual and job characteristics on 'burnout' among civil engineers in Australia and the implications for employee turnover', Construction Management and Economics, 21 (1), 69-80.

Lingard, H. \& Francis, V. 2004, 'The work-life experiences of office and site-based employees in the Australian construction industry', Construction Management and Economics, 22 (9), 991-1002.

Lingard, H, Brown, K, Bradley, L, Bailey, C. \& Townsend, K. 2007, 'Improving Employees' Work-Life Balance in the Construction Industry: Project Alliance Case Study', Journal of Construction Engineering and Management, 133 (10), 807-815.

Lingard, H.C, Francis, V. \& Turner, M. 2010, 'The rhythms of project life: a longitudinal analysis of work hours and work-life experiences in construction', Construction Management and Economics, 28 (10), 1085-1098.

Locke, E.A. 1976, 'The nature and causes of job satisfaction', in M.D. Dundee \& L.M. Hough (eds), Handbook of industrial and organizational psychology, Rand-McNally, Chicago.

Loher, B.T, Noe, R.A, Moeller, N.L. \& Fitzgerald, M.P. 1985, 'A meta-analysis of the relation of job characteristics to job satisfaction', Journal of Applied Psychology, 70 (2), 280-289.

Lynn, S.A, Cao, L.T. \& Horn, B.C. 1996, 'The influence of career stage on the work attitudes of male and female accounting professionals', Journal of Organizational Behavior, 17 (2), 135-149.

Maloney, W. \& McFillen, J. 1985, 'Valence of and Satisfaction with Job Outcomes', Journal of Construction Engineering and Management, 111 (1), 53-73.

Marzuki, P.F, Permadi, H. \& Sunaryo, I. 2012, 'Factors Affecting Job Satisfaction of Workers in Indonesian Construction Companies', Journal of Civil Engineering and Management, 18 (3), 299-309.

Maslach, C, Schaufeli, W.B. \& Leiter, M.P. 2001, 'Job Burnout', Annual Review of Psychology, 52 (1), 397-422.

Morrow, P.C. \& McElroy, J.C. 1987, 'Work commitment and job satisfaction over three career stages', Journal of Vocational Behavior, 30 (3), 330-346.

Neuman, W.L. 2006, Social research methods : qualitative and quantitative approaches, 6th edn, Pearson/Allyn and Bacon, Boston.

$\mathrm{Ng}$, T.W. \& Feldman, D.C. 2009, 'Age, work experience, and the psychological contract', Journal of Organizational Behavior, 30 (8), 1053-1075.

$\mathrm{Ng}$, T.W.H \& Feldman, D.C. 2010, 'Idiosyncratic deals and organizational commitment', Journal of Vocational Behavior, 76 (3), 419-427.

Onukwube, H.N. 2012, 'Correlates of job satisfaction amongst quantity surveyors in consulting firms in Lagos, Nigeria', Australasian Journal of Construction Economics and Building, 12 (2), 43-54.

Oshagbemi, T. 2000, 'Is length of service related to the level of job satisfaction?', International Journal of Social Economics, 27 (3), 213-226.

Hosseini M R, Chileshe N \& Zillante G. 2014, 'Investigating the factors associated with job satisfaction of construction workers in South Australia’, Australasian Journal of Construction Economics and Building, 14 (3), $1-17$. 
Pagán, R. 2011, 'Ageing and disability: Job satisfaction differentials across Europe', Social Science \& Medicine, 72 (2), 206-215.

Pagán, R. 2013, 'Job Satisfaction and Domains of Job Satisfaction for Older Workers with Disabilities in Europe', Journal of Happiness Studies, 14 (3), 861-891.

Park, H, Baker, C. \& Lee, D. 2008, 'Need for Cognition, Task Complexity, and Job Satisfaction', Journal of Management in Engineering, 24 (2), 111-117.

Porcellato, L, Carmichael, F, Hulme, C, Ingham, B. \& Prashar, A. 2010, 'Giving older workers a voice: constraints on the employment of older people in the North West of England', Work, Employment \& Society, 24 (1), 85-103.

Reich, W.A, Wagner-Westbrook, B.J. \& Kressel, K. 2007, 'Actual and Ideal Conflict Styles and Job Distress in a Health Care Organization', The Journal of Psychology, 141 (1), 5-15.

Roelen, C.M, Heymans, M, Twisk, J.R, Klink, J.L, Groothoff, J. \& Rhenen, W. 2014, 'Work Ability Index as Tool to Identify Workers at Risk of Premature Work Exit', Journal of Occupational Rehabilitation (in press).

Ruthankoon, R. \& Ogunlana, S.O. 2003, 'Testing Herzberg's two-factor theory in the Thai construction industry', Engineering, Construction and Architectural Management, 10 (5), 333-341.

Sarker, S.J, Crossman, A. \& Chinmeteepituck, P. 2003, 'The relationships of age and length of service with job satisfaction: an examination of hotel employees in Thailand', Journal of Managerial Psychology, 18 (7), 745-758.

Sweis, R.J. (2010), 'The Relationship between Information Technology Adoption and Job Satisfaction in Contracting Companies in Jordan', Journal of Information Technology in Construction, 15, 44-63.

Templer, K.J. 2012, 'Five-Factor Model of Personality and Job Satisfaction: The Importance of Agreeableness in a Tight and Collectivistic Asian Society', Applied Psychology, 61 (1), 114-129.

Toole, T.M, Hallowell, M. \& Chinowsky, P. 2013, 'A tool for enhancing innovation in construction organizations', Engineering Project Organization Journal, 3 (1), 32-50.

Verma, J.P. 2013, Data Analysis in Management with SPSS Software, Springer, New Delhi, India.

Watson, M. 2012, 'Concerns for skills shortages in the 21st century: a review into the construction industry, Australia', Australasian Journal of Construction Economics and Building, 7 (1), 45-54.

Weiss, H.M. 2002, 'Deconstructing job satisfaction: Separating evaluations, beliefs and affective experiences', Human Resource Management Review, 12 (2), 173-194.

Yirenkyi-Finako, A.B. \& Chileshe, N. 2012, 'Job satisfaction of professionals within the Ghanaian construction industry', in S.D. Smith (ed), 28th ARCOM Conference, Association of Researchers in Construction Management, 3-5 September, Edinburgh, UK, 589-599.

Zhou, K.Z, Li, J.J, Zhou, N. \& Su, C. 2008, 'Market orientation, job satisfaction, product quality, and firm performance: evidence from China', Strategic Management Journal, 29 (9), 985-1000.

Hosseini M R, Chileshe N \& Zillante G. 2014, 'Investigating the factors associated with job satisfaction of construction workers in South Australia’, Australasian Journal of Construction Economics and Building, 14 (3), $1-17$. 